\title{
Analysis on the Policy Effect of Replacing Business Tax with Added-Value Tax
}

\author{
Shaogang Liao, Ying Pan \\ School of Public Finance and Public Administration, Jiangxi University of Finance and Economics.169\#Shuanggang East Street, Nanchang, \\ China
}

\section{Email address:}

liaoshaogang@163.com (Shaogang Liao)

\section{To cite this article:}

Shaogang Liao, Ying Pan. Analysis on the Policy Effect of Replacing Business Tax with Added-Value Tax. International Journal of Economics, Finance and Management Sciences. Vol. 3, No. 3, 2015, pp. 162-171. doi: 10.11648/j.ijefm.20150303.13

\begin{abstract}
In August 2013, the policy of replacing business tax with added-value tax (hereinafter referred to as VAT) was formally popularized to the whole national. It was an important measure of China comprehensively deepening the reform, readjusting the industrial structure and promoting the economic development. On the micro and macro aspects, the political effect of the policy of replacing business tax with VAT is analyzed in this paper from the time of trial implement to being carried out although the country. From the micro aspect, the analysis is based on the impact of the policy on the producers, consumers and the demand for labors. From the macro aspect, the analysis is based on the impact of the policy on the budget management system, industrial structure and fair income distribution. At the same time, the paper analyzes the problems, which appeared since the policy had been carried out for a year and gives some suggestions from the angles of actual operation and implementation. It could provide the beneficial reference to improve the policy of replacing business tax with VAT.
\end{abstract}

Keywords: Replacing Business Tax with VAT, Micro-Effect, Macro-Effect, Industrial Structure, Perfect Tax System

\section{The Theoretical Basis and Realistic Background of the Implementation of the Policy of Replacing Business Tax with VAT}

From January 1, 2012, The China State Council decided to implement the policy of replacing business tax with a VAT in Shanghai's transportation industry and some modern service industries. Since that time, China's VAT reformation began. After the trial implementation over one year, on August 1, 2013, the policy of replacing business tax with VAT was carried out throughout the whole country. The goods and service tax reform of China was made the substantial progress.

\subsection{The Theoretical Basis of the Policy of Replacing Business Tax with VAT}

From the theoretical aspect, the policy of replacing business tax with VAT is determined by the characteristics of business tax and VAT. On one hand, the whole amount of Business tax is the base of accounting the business tax, without any tax deduction. However, the value-added amount of all links is the base of accounting VAT, deducting the input tax of the upper class link. Therefore, there is double taxation in business tax, which is not beneficial for reducing the tax burden of enterprises. On the other hand, thinking from the angle of Economics, VAT means to tax the labor compensation value and surplus product value, which taxes the wages and profits. In the scope of business tax, the main body of business tax includes wages and profits. Therefore, replacing business tax with VAT is reasonable.

\subsection{The Realistic Background of the Policy of Replacing Business Tax with VAT}

\subsubsection{The Needs of Structural Tax Cuts}

The policy of replacing business tax with VAT was implemented in the background of china carrying out the structural tax cuts in order to face the international financial crisis. Therefore, replacing business tax with VAT, in a sense, is needed by implementing the national structural tax cut. The structural tax cut means to improve the vitality of the markets, stimulate economic growth by deducing the tax burden of some industries and enterprises on the basis of ensuring the state's financial income. For a long time, the burden of the tax payers who need to pay the business tax had been being very 
heavy. From chart 1, we can see, from 2008 to 2012, the growth rate of business tax was greatly higher than that of VAT and the national total tax income, in which the average growth rate of business tax was $19.22 \%$, nearly $8 \%$ higher than the average growth rate of VAT. So in the background of structural tax cuts, implementing the policy of replacing the business tax with VAT is benefit for cutting the whole tax burden of the business tax payers, improving the market activity and complying with the inner needs of structural tax cuts.

\subsubsection{The Needs of Adjusting the Industrial Structure and Promoting the Economic Transition}

The core field of implement the new tax policy is the modern service industry. And Service industry is an important engine measuring the quality of a nation's economic development level.

Charter 1. Business Tax VS VAT (Unit: billion)

\begin{tabular}{lllll}
\hline Year & Income of usiness Tax & $\begin{array}{l}\text { Growth Rate of } \\
\text { Business Tax }\end{array}$ & Income of VAT & $\begin{array}{l}\text { Growth Rate of VAT } \\
\text { Growth Rate of Total } \\
\text { Income of Tax Revenue }\end{array}$ \\
\hline 2008 & $7,626.39$ & $16.41 \%$ & $17,996.94$ & $16.32 \%$ \\
2009 & $9,013.98$ & $18.18 \%$ & $18,481.22$ & $2.70 \%$ \\
2010 & $11,157.91$ & $23.77 \%$ & $21,093.48$ & $14.10 \%$ \\
2011 & $13,679.00$ & $22.60 \%$ & $24,266.63$ & $15.10 \%$ \\
2012 & $15,747.64$ & $15.12 \%$ & $26,415.51$ & $8.85 \%$ \\
Average growth rate & -- & $19.22 \%$ & -- & $11.41 \%$ \\
\hline
\end{tabular}

Data sources: The National Bureau of Statistics.

Carrying out the policy of replacing business tax with VAT has its own realistic significance of adjusting the industrial structure, promoting the development of modern service industry, economic transition and upgrade. In the international society, the contribution rate of service industry in the world's major developed countries to economic growth is generally above $70 \%$. The service industry has become the main power of improving economic growth. But look from the reality (look at the Charter 2), the contribution rate of the third industry of China to economic growth was about $45 \%$,much lower compared with that in the developed countries, which meant the unreasonable industrial structure of China.

Charter 2. The Contribution Rate of the Three Major Industries to Economic Growth (Unit:\%)

\begin{tabular}{lllll}
\hline Year & $\mathbf{2 0 0 8}$ & $\mathbf{2 0 0 9}$ & $\mathbf{2 0 1 0}$ & $\mathbf{2 0 1 1}$ \\
\hline The contribution rate of The First Industry & 5.7 & 4.6 & 3.8 & 4.5 \\
The contribution rate of The Secondary Industry & 48.7 & 51.6 & 56.8 & 51.9 \\
The contribution rate of The Tertiary Industry & 45.6 & 43.8 & 39.3 & 49.3 \\
\hline
\end{tabular}

Data sources: The National Bureau of Statistics.

Meanwhile, in the view of development quality, Chinese service industry are mainly concentrated on the traditional service areas, barely on the modern service areas. Due to the parallel relationship of business tax and VAT, the phenomenon of "service built-in" in manufacturing enterprises is obvious, which is not beneficial for professional division of labor and the development efficiency of service industry. Consequently, by pursuing the policy of replacing business tax with VAT, the overall tax burden of service industry could be further reduced The policy can be carried out to lay the foundation of the development of modern service industry, raise the proportion of the third industry and adjust the structure of the national economy.

\subsubsection{The Needs of Market-Oriented Reforms}

In the process of comprehensively deepening reform, China clearly pointed out that the decisive role of market must be played during the allocation of resources. The VAT has tax neutrality, less influencing the market behavior of economic subjects. The market mechanism can play a role fully. However, the business tax implements different tax rates to different industries, which greatly influences the market behavior. Consequently, replacing business tax with VAT benefits for VAT playing a tax neutral role, making the market allocate the resources, which is in accordance with the needs of china's market-oriented reform

\section{Microscopic Effects of the Policy of Replacing Business Tax with VAT}

\subsection{Influence of the Policy of Replacing Business Tax with VAT on the Producers}

Those who are influenced deeply by the policy of replacing business tax with VAT are producers, also called the relevant taxpayers. We could analysis the impact of the policy on the relevant enterprises from four aspects: Tax reduction effect, investment effect, innovation effect and trade effect.

\subsubsection{Tax Reduction Impact of the Policy Replacing Business Tax with VAT on the Enterprises}

After change of the tax policy, the input tax of equipments and services purchased by service industries could be deducted in the output tax, which solves the problem of duplicate taxation, making the overall tax burden of service enterprises decreased. In April 2014, the State Administration of Taxation announced the relevant data of the new tax policy in the first quarter. According to the data, we could see that the tax burden of enterprises was reduced about 37.5 billion Yuan in the first quarter of 2014. Since the policy was first tried out 
in 2012 to the present, the tax burden of enterprises have been reduced totally about 220.3 billion Yuan. The policy of replacing business tax with VAT has an obvious effect on reducing tax burden. Taking Shanghai's transportation enterprises which were greatly influenced by the policy as an example, the overall tax burden of Shanghai's transportation enterprises declined (look at the Charter 3) according to the data released by Shanghai government. The quarterly industry-wide tax reduction amount was about 170 million Yuan, the annual tax reduction amount was totally about 750 million Yuan.

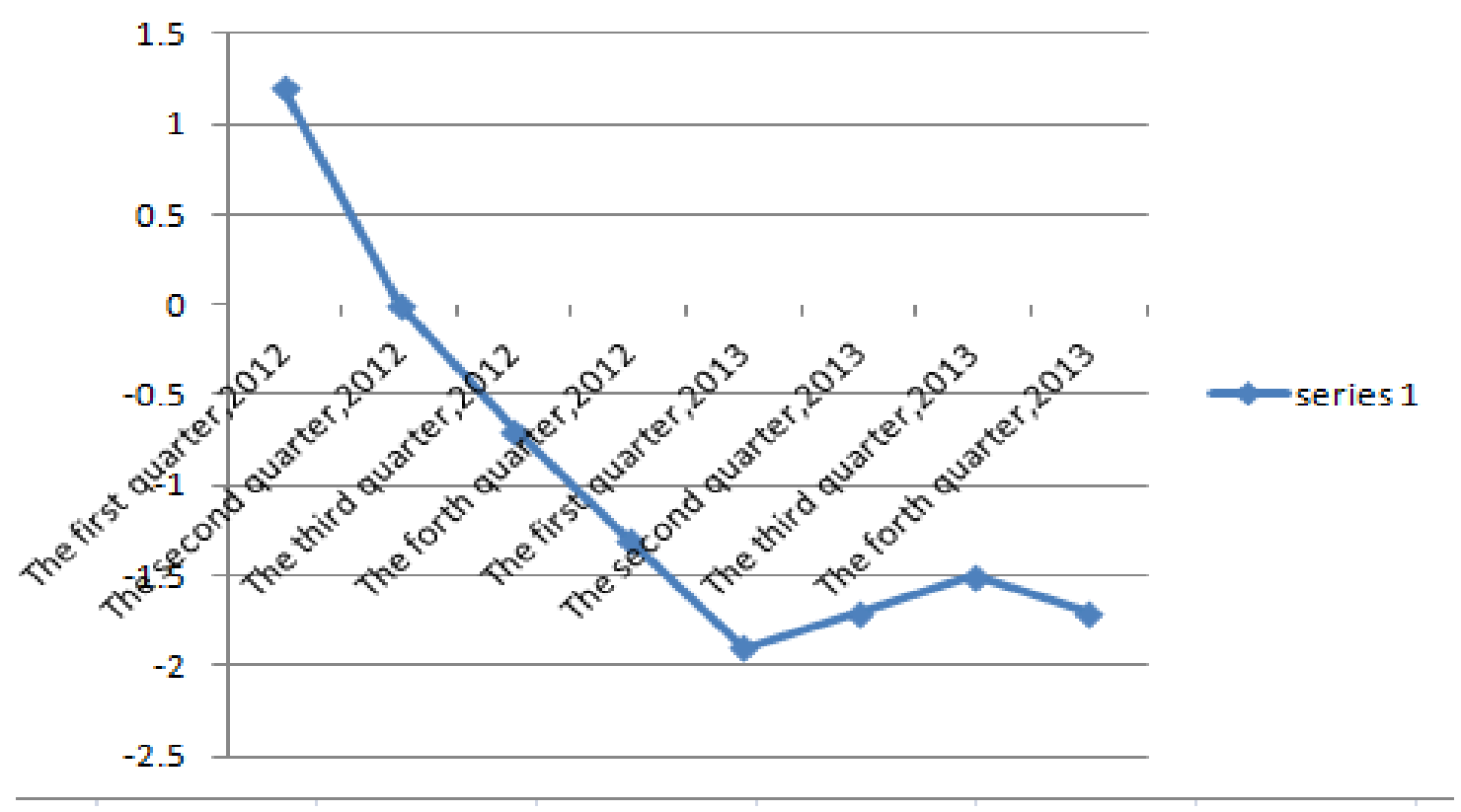

Data resources: the websites of the State Taxation Bureau and local taxation Bureau of Shanghai.

Chart 3. Tax reduction data of transportation industries in Shanghai (Unit: one hundred million Yuan)

At the same time, the number of transportation enterprises in Shanghai was increased $42 \%$ in two years, which reflected the obvious effect of the new tax policy of replacing business tax with VAT, mobilized the vitality of enterprises.

The function of tax reduction of the policy of replacing business tax with VAT is realized mainly through the following ways. Firstly, the policy eliminates the parallel relations between business tax and VAT. The business tax can be deducted by the input tax and the problems of duplicate taxation can be solved after the merger of the two taxes. Secondly, setting the tax rates of related service enterprises could help to cut taxes. The higher the tax rate is, the less obvious the effect of tax cuts in enterprises is. The lower the tax rate is, the better the effect of tax cuts in enterprises is. Consequently,in the process of implementing the new tax policy, it is extremely important to correctly evaluate the overall tax burden of industries and set the reasonable related tax rates. Thirdly, continue to implement the preferential tax policy. In the process of tax reform, the documents issued by State Administration of Taxation clearly specified the tax breaks policy, which was helpful to reduce the tax burden of enterprises.Fourthly,enterprise's price game ability. In the process of tax refrom,because an input tax could be deducted and VAT special invoices could be issued ,it benefits the tax shifting in enterprises. Enterprises' tax burden will be declined if the enterprises can shift the tax burden better in the process of business game.

\subsubsection{Investment Impact of the Policy of Replacing Business Tax with VAT on the Enterprises}

Since January 2009, our country fully implemented the consuming VAT, which benefited for enterprises to increase the investments of machinery and equipments and promote the upgrade of the enterprise equipments. But before the reform of replacing business tax with VAT, the equipments purchased by the enterprises who paid to business tax could not deduct the input tax, leading to the lack investments to the machinery and equipments and affecting the development of enterprises. Through the reform of replacing business tax with VAT, the equipments, means of production and outsourced services of related enterprises can deducted the input tax. To those enterprises who need large-scale investments and updated equipments, the tax burden could be decreased. It can encourage enterprises to accelerate the technological updates, speed up the equipment introduction, increase the investments on equipments and strengthen the enterprise development.

The implementation of replacing business tax with VAT helps enterprises to increase the related equipment investments, at the same time, it also promote enterprises to increase the investments to other related fields. On one hand, the police of replacing business tax with VAT makes the overall tax burden of benefited enterprises down, increases the disposable personal income. Under the function of tax income effect, the enterprises increase the investments to some programs, which would make profits, in order to get more 
economic benefits, optimize the corporate profit structure, raise the level of overall profits. On the other hand, because of the implement of the new tax policy, the tax burden of some relevant industries decreased, some enterprises with heavy tax burden turned to invest the service industry, transportation industry and so on. According to the data issued by Shanghai and Beijing, influenced by the tax reform, the market demand of some relevant industries kept increasing, investment willingness kept growing and industry scale expanded rapidly. After one-year trial implementation in Shanghai and Beijing, among the transport, among the transportation industry, the number of enterprises' raised from 55636 and 2265 to 6228 and 3074 respectively. The investment effect was obvious[1].

\subsubsection{Innovation Effect of the Policy of Replacing Business Tax with $V A T$}

On the enterprises mainly reflects the following two aspects. Firstly, through the tax reform, avoiding the double taxation and speeding up the paces of updating the enterprise equipments, it leads the enterprises to use and introduce the advanced equipments. So the quality of products and services of enterprises is increased and the innovation ability of enterprises is improved.Secondly, through the tax reform, it brings the business model innovation. For a long time, because of the parallel relations between business tax and VAT, hybrid sales activity was the problems which enterprises were difficult to solve. If relevant service departments get independent, they need to pay business tax and could not deduct the input tax, which would increase the burden of enterprises. For this reason, most enterprises internally install the service departments, which is opposite to the division of labor of social production. The implementation of policy of replacing business tax with VAT makes the independent service departments deduct VAT, without affecting the overall tax of enterprises. It benefits for the professional division of labor, separating business departments' from service departments, promoting the development of outsourcing service, extending industrial chain, extending some relevant businesses and innovating business models.

\subsubsection{Trade Impact of the Policy of Replacing Business Tax with VAT on the Enterprises}

Service trade is an important part of a nation's trade. Because the service industry mainly pays the business tax without deduction, it leads that the real zero tax rate doesn't appear in the export products. Unlike the VAT, the business tax can't enjoy the export rebates. So it seriously impacts the trade of service industry of China. According to the trade deficit Constitute of China's service industry in 2012 issued by Ministry of Commerce(look at the Chart 4),

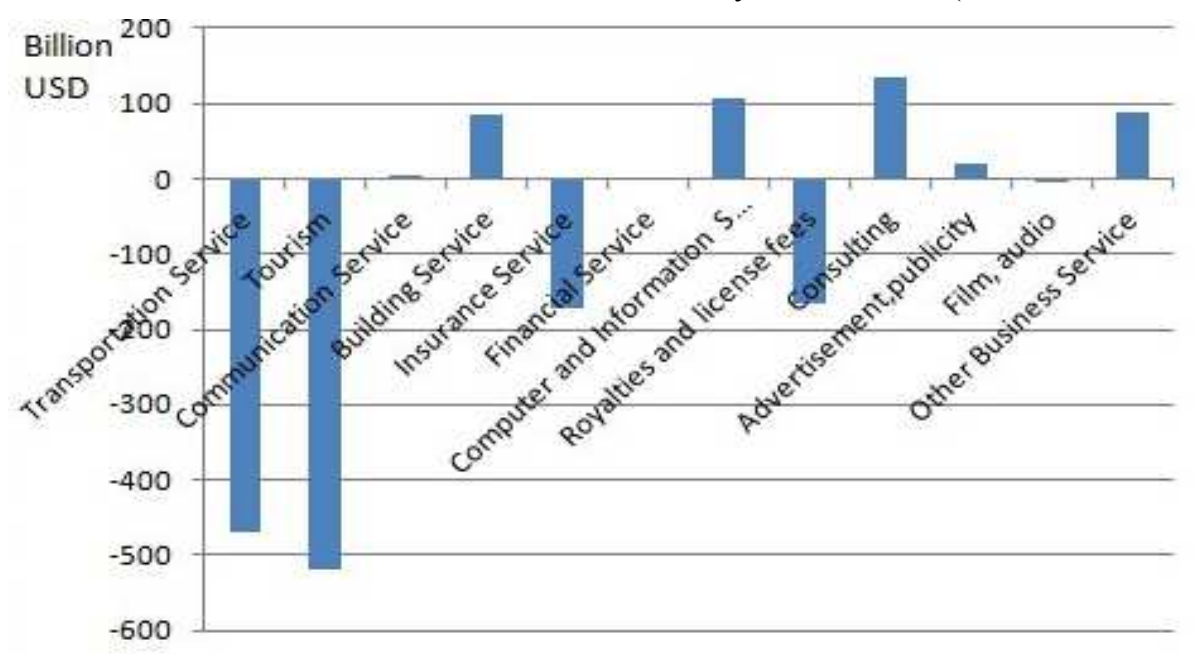

Data resources: the website of Chinese Service and Trade.

Chart 4. Trade Deficit Constitute of China's service industry in 2012

The trade deficit of service industry was obvious, especially in the traditional transportation industry and insurance industry. The business tax constituted the relevant costs, severely restricting the international competitiveness of transportation and insurance industries.

After implementation of the policy of replacing business tax with VAT, international transportation services and research and design business can enjoy the export tax rebates, in accordance with the business of VAT. This will further reduce the tax burden of service and trade industries, help them to enter into the international market with the zero tax rate and improve the international competition abilities. According to the information announced by the State Administration of
Taxation, in 2012 and 2013 when the policy was put into trial use in Shanghai ,the amounts of export trade was respectively increased 22.4 billion Yuan and 24.2 billion Yuan .Especially in 2013,the service trade amount was increased $18 \%$,presenting a booming situation.[2]

\subsection{Impact on Consumers of the Policy of Replacing Business Tax with VAT}

Consumers are the important participants of the market economic activities. The function of the policy of replacing business tax with VAT must affect the consumers' behavior. On one hand, the impact of the policy on the consumers would be realized through the market game to affect service 
environment and service quality. On the other hand, It will be realized through the substitution of taxation. As stated earlier, replacing business tax with VAT can produce innovation and investment benefits, which would increase the number of competitive enterprises in the related services fields, upgrade the market dynamics. Under the conditions of the full market competition, the relevant procedures and rules will be set up and improved gradually and service environment will be improved constantly. To the consumers, It would be better to protect their reasonable rights and interests. At the same time, because of the increasing number of the competitive enterprises and competition behavior appearing frequently, strategy of quality would be the choice of many service enterprises. So consumers can enjoy more high quality services.

The impact of the new tax policy on the consumers is also realized through tax substitution effect. The policy changes the relative prices of the service products and related goods, guiding the consumers to choose more service products and affecting consumers 'choices.

\subsection{The Impact on Labor Demand of the Policy of Replacing Business Tax with VAT}

Service industry is an important industry absorbing employment. According to the data released by the National Bureau of Statistics, in China, the number of employees of the third industry reached to $35.7 \%$ of the whole employees in 2011, more than that of the first and second industry. In the national 12th five-year program, the government had clearly pointed out that by the end of the period, $4 \%$ need to be added on the base of the previous percent. However, compared with the world average data, there is still a large gap. With carrying out the policy of tax reform, the kind of condition could be changed.

\subsubsection{The Impact on Labor Demand of the Policy of Replacing Business Tax with VAT}

Through the analysis above, replacing business tax with VAT can promote the further development of service industry effectively, which is the main industry of a country to absorb employment. Consequently, the policy of replacing business tax with VAT will provide more jobs. Through the calculation of Shanghai Tax Bureau, in 2012 and 2013, the increased number of employment were 146,000 and 145,000 respectly,which was influenced by the policy. In the meantime, comparing with the pilot industries and non-pilot industries, the employment rate of pilot industries in 2013 increased $20.5 \%$, more than that in $2012,7 \%$ higher than that of the non-pilot industries and 18\%higher than the average employment rate in Shanghai. This data shows that the implementation of the policy plays an important role in meeting the demands of Labor.

\subsubsection{The Impact on Labor Demand Structure of Policy of Replacing Business Tax with VAT}

Replacing business tax with VAT not only meets the quantity demand of employment, also has a significant impact on labor demand structure. On one hand, the implementation of the policy will promote the development of construction, transportation and other traditional service industries, realizing the coordination of the industrial structure and labors structure, guiding the labor resources to flow from the first and second industry to the third industry. on the other hand, the implementation of the policy will also promote the development of modern service industries, such as Postal and Telecommunications Industry, Financial Industry and Cultural and Sports Industry and so on. The modern service industry has the feature of high intelligence and high technology, which puts forward the higher requirements to the labors. Therefore, the implementation of the policy of replacing business tax with VAT is good for the high-quality talents flowing into the modern service industries and forming the high-quality and high intelligence human resource structure. [3]

\section{The Macro Impact of the Policy of Replacing Business Tax with VAT in China}

The influence of this policy on macro economy can be analyzed mainly from the following three aspects: the system of the budget management, industrial structure and the income distribution fairness.

\subsection{The Impact of the Policy of Replacing Business Tax with VAT Policy on Budget Management System}

Government budget management system refers to a system dealing with all levels of financial allocation relationships in a country's financial system, of which the core is the tax distribution relationships.

The influence of the new tax policy on government's budget management system can be analyzed from the three following aspects: the impact on income distribution, perfecting the tax system and the tax collection and administration system.

\subsubsection{The Influences of the Policy of Replacing Business Tax with VAT on the Income Distribution}

Before replacing business tax with VAT, in our country, business tax was the main tax revenue of local governments, $15 \%$ of total national tax income, about $33 \%$ of total local tax income. After replacing business tax with VAT, the original business tax can was collected by the centre and local governments in accordance with the proportion of $75 \%$ and $25 \%$, which seriously affected the local governments' income. Then following data is the income of national business tax and VAT in 2012. Let's make a simple analysis. In 2012, the national VAT income was about 2641.551 trillion Yuan, the business tax income was about 1574.764 billion Yuan. Before the implementation of replacing business tax with VAT, tax revenue of the local governments was $2.6415 * 25 \%+1.5747$ trillion Yuan, which was 2235.151 billion Yuan. After carrying out this policy, total income of the local governments, including the business tax and VAT, the number was $(26415.51+26415.64) * 25 \%$, which was 1054.079 billion 
Yuan. Through the contrast, 1181.072 billion Yuan of the local governments' tax income was reduced. Therefore, the implementation of the new tax policy made obvious effects on tax income distribution.

\subsubsection{Influence on Perfecting the Tax System of the Policy of Replacing Business Tax with VAT}

The current budget management system in our country is tax distribution system. In the system, central and local financial allocation is determined by the tax category on the basis of delimiting the power or authority of governments. After carrying out VAT instead of business tax, the local governments did not have enough money, which meant the corresponding functions of the governments would be seriously affected. Even in some places which had the insufficient tax income, the phenomenon of public finance liabilities appeared. After the new policy was implemented by the central government, solution to the local tax income reducing was the intergovernmental transfer payments, which reduced the financial pressure of those governments and relieved the contradictions between the central and local governments. However, the fundamental way of solving the insufficient local income is to improve the existing tax system, accelerate the development of tax, open up a new way of local tax income and improve actively the new distribution system of finance and power rights between local and central governments.

\subsubsection{The Influence on the Tax Collection and Administration System of the Policy of Replacing Business Tax with VAT}

According to Chinese current tax law, VAT is generally levied by the state administration of taxation and the business tax is collected by the local taxation bureau. After carrying out the new policy, the business tax, which was collected by the local taxation bureau in the past, is collected by the national tax departments. the Types of taxes levied by the local taxation bureau were further reduced, which affected the relationship and management between the two institutions. And in Shanghai, which was the place of trial implementation, due to the union of the state administration of taxation and local taxation bureau, it was not a big problem on coordination. However, as the implementation of the new policy nationwide, solutions to the coordination and administration of national tax and land tax become more important.

\subsection{The Influence on Industrial Structure of the Policy of Replacing Business Tax with VAT}

One of the important reasons of replacing business tax with VAT is to promote the service industry development in our country, adjust the industrial structure and promote the economic transformation. The impacts on industrial structure of this policy are mainly showed in two aspects, including the adjustment to the proportion of the three industries and the internal structure of service industry.

\subsubsection{The Adjustment of the Policy to the Proportion of Three Industries}

Replacing business tax with VAT, on one hand, reduces the tax burden of the overall service industry. On the other hand, it opens up the deduction link between the second and the third industry and extends the deduction chain so that the upstream and downstream of service industry can be mutually connected and integrated. Service industry has the characteristics of high input and output, fast money collection. So it could guide the social resources to flow to the third industry, change the proportion of the three industries' structure, thus realizing the adjustment of industrial structure. According to the relevant statistics of some local tax authorities because of the influence of the policy, in the first three quarters of 2013, the added value of third industry in Guangdong province was 2090.372 billion Yuan, increased $10.1 \%$ compared with that of last year, making the contribution rate of $52.8 \%$ to the provincial economy, promoting economic growth of $4.5 \%$,among which the proportion of service industry reached to $47.8 \%$. It was the first time that the proportion of service industry exceeded the second industry and reached to a higher level in the history. Similarly, in 2012 and 2013 in Shanghai, influenced by the policy, the proportion of the third industry reached to $60 \%$, which it was $60.45 \%$ in $2012,62.23 \%$ in 2013 and realized the historical leap. From the statistics all over the world, the effect of the tax policy on improving the proportion of the third industry is very obvious. 


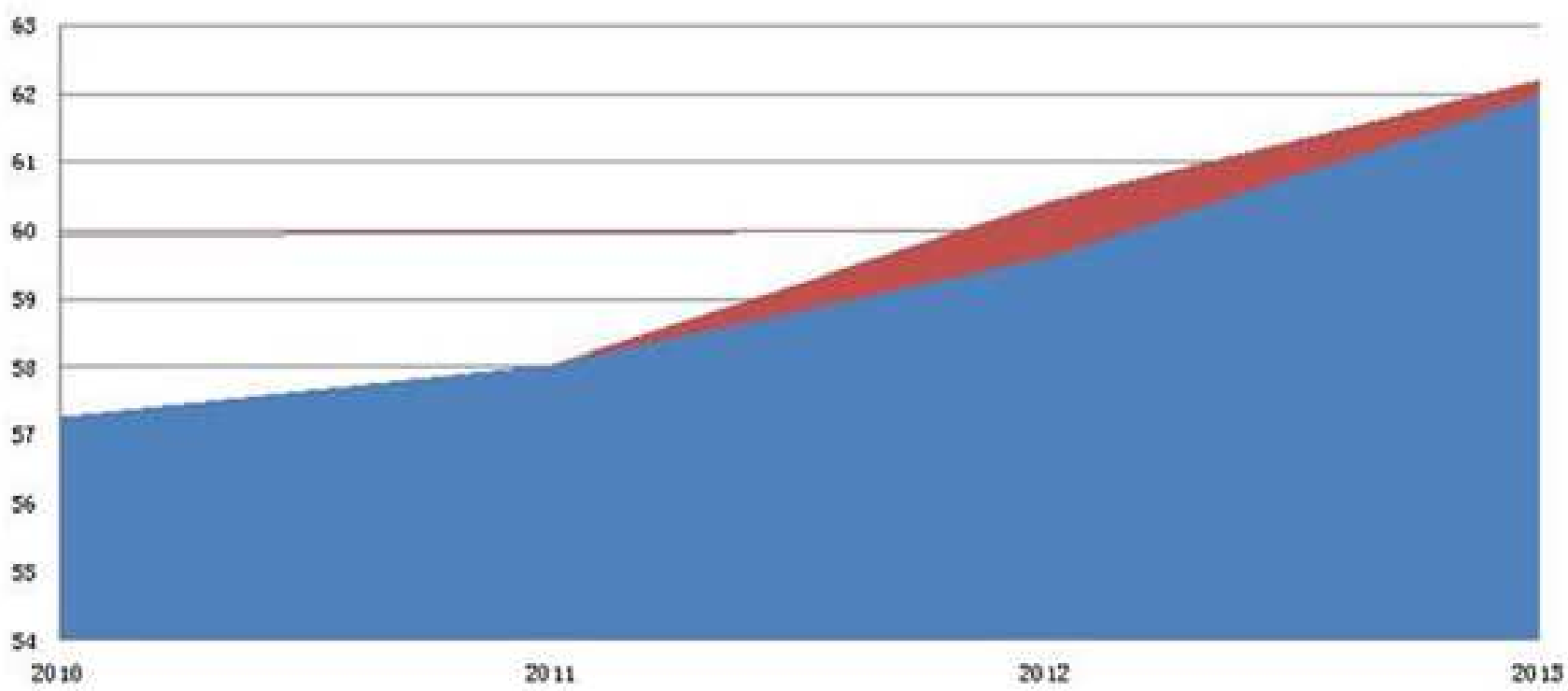

proportion of the third industry

effect of VAT

Data resources: the state tax bureau of Shanghai.

Chart 5. The tax policy improving the upgrading of industrial structure in Shanghai

\subsubsection{The Adjustment to the Internal Structure of Service Industry of the Tax Policy}

As while as the policy of replacing the business tax with VAT adjusting the proportion of the three industries, it also affects the internal structure of the third industry. The so-called internal structure adjustment is that realizing the development from the traditional service industry to the modern service industry. The following two points are the main way to achieve this transformation: one is that the tax burden of some modern service industries, which have many deductible items, fell down more obviously, compared with the traditional service industries. Second, the new tax policy promotes some enterprises to separate the main business from auxiliary business, promotes the professional coordination. The enterprises could take some business to the logistic companies and culture creative companies so as to focus on the development of core business and the improvement of ability, further promoting the internal structural adjustment. According to the statistics of the taxation authorities in Hubei, Shanghai, Guangdong and other places, in Hubei, the mainly benefited enterprises were mainly in the new industries, such as the visa consulting services, cultural creative services, road transportation services. And in Hubei province in 2013, in the rank of tax contribution, located in the top five industries were all the modern service industries, such as road transportation service industry, research and technical service industry, cultural creativity industry, logistics support service industry and pipeline transportation service industry.

In 2012 and 2013 in Shanghai, the policy promoted the modern service industry to increase $8.72 \%$ and $2.76 \%$ respectively. Meanwhile, in Guangdong province, which carried out the new tax policy, cultural creative service industries, research and technical service industries and other modern service industries grew rapidly.

\subsection{The Influences on the Income Distribution Fairness of the Policy of Replacing Business Tax with VAT}

Tax is the important tool of regulating income distribution used by the government. During the process of past 35-year reform and development in China, the income gap got wider and wider, which the gins coefficient was more than 0.4 cordon. One of the important reasons was that in China in the tax system structure, indirect tax was the priority tax, the proportion of the income tax, regulating the income distribution, was too small.

Samuelson once said, "in the tax system of high income countries, the progressive effects of individual income tax are offset by the regressive taxes, such as sales tax or VAT, the tax system has little influence on the income distribution[4].As the VAT has the characteristics of regressive. Residents' marginal propensity to consume marginal would be declined, which eventually lead to the results that the low-income earners bear more tax burdens than that of the high-income earners. It isn't conducive to narrow the gap between the rich and poor. At the same time, according to the Zhou Xiaoling and $\mathrm{Hu}$ bing (2011)'s calculation to the goods and services tax of China from 2002 to 2009 , the taxes urban taken by the city residents seriously offsets the positive effects of the income tax to the income distribution. Therefore, in the process of promoting the new tax policy in China, as the business tax which has more obvious adjustment to the income distribution is being replaced by the VAT which has the obvious characteristics of regressive. To some extent, it enlarges the 
unfair distribution, affects the social welfare, and weaken the effect of tax reduction of the new tax policy.

\section{Some Problems of the Policy of Replacing Business Tax with VAT and Some Suggestions for Improvement}

\subsection{Some Problems of the Policy of Replacing Business Tax with VAT}

Replacing business tax with VAT has the positive effects to Chinese economy. However, there are still some problems of the policy.

\subsubsection{Excessive Tax Levels Distort Tax Neutrality}

According to "the notice about implementing the pilot tax policy in the transportation industry and modern service industry throughout the country" (caishui [2013] No.37) . after replacing the business tax with VAT in our country, the original tax rate were divided into four levels, two levels $11 \%$ and $6 \%$ added. In the process of replacing the business tax with VAT, setting up multiple levels does help to reduce the tax burden of different industries.

However, the more levels the rates were set, the more complicated the tax management became, the more influences on the VAT tax neutrality. In the chain of VAT deduction, for example, in a general taxpayer enterprise, its products' applicable tax rate is $17 \%$. But its related services purchased can only be deducted by $11 \%$. Then, there is $6 \%$ of the tax amount of the enterprise that can't be deductible. This will inevitably affect the market behavior of enterprises, and distort the VAT tax administrative principles.

\subsubsection{Lack of Reasonable Arrangement of Tax Income Leads to the Struggle Between the Central Government and Local Governments}

The background of replacing the business tax with VAT in our country is still the budget management system and system of tax distribution. And the premise of these systems is the reasonable division to financial powers. And in the process of the reform of tax distribution system in 1994, financial rights were gradually handled by the central government and administrative rights were gradually handled by the local governments. Before the implementation of the new tax policy, the local governments had been facing the problems of insufficient financial income, land finance and debt finance. Since 2012, the business tax, the important income source of the local governments had been replaced with VAT. It made the local governments only share $25 \%$ of the total tax income, which made the local finance more difficult.

At the present, the main solution to this problem is to increase the intergovernmental transfer payments, and maintain the local governments' income level. However, this method adds the dependence of the local governments to the central government, severely weaken the financial autonomy of local governments. At the same time, this method does not fundamentally solve the problems of the division of the finance rights and administrative rights in the system of tax distribution. Instead, it will lead to the struggle between the local governments themselves or the central government and local governments, competing for the limited financial resources.

\subsubsection{Put Forward the New Challenges to Tax Collection and Administration}

The new tax policy puts the new challenges to the existing tax collection and administration system. The challenges are mainly from two aspects. One reason is the several levels of rates. As four levels of tax rates were carried out in our country in the process of replacing the business with VAT, it provided the convenience to the related enterprises dealing with output tax [5].Because when calculating the output tax, enterprises can select multiple tax rates to deal with the mixed business .Tax authorities are difficult to identify its authenticity. On the other hand, the new challenge comes from the management of invoices. As the business tax in China is collected by the local taxation bureau, and VAT is collected by the state administration of taxation, the VAT invoice authentication system exists only in the national tax departments, it makes that in the process of replacing business tax with VAT, qualified VAT taxpayer was not included in the related systems of national tax departments. Therefore, at the beginning of carrying out the new policy, certification, inspection, assessment to those enterprises invoice have some problems.

\subsubsection{Some Other Taxes don't Follow Up, Lack of Take All Things into Consideration}

Replacing the business tax with VAT was carried out under the condition of structural tax reduction was implemented in our country. Therefore, the policy should also be considered under the tax system. According to the above analysis, in the process of the policy in our country, on the one hand, due to the undeveloped local tax system, local governments were lack of effective financial supports and had the decreased financial income; On the other hand, due to the regressive character of VAT, it led the poor effect on the aspect of fair income distribution. And in our country, during the implementation of the policy, the taxes, which well adjust the distribution of income, aren't reformed.

\subsubsection{The Tax Burden Rise in Some Industries}

Replacing the Business tax with VAT is an important part of structural tax cuts. The so-called structural tax cuts means that its tax burden is bound to rise and fall. But what must be emphasized here is the reason of tax burden rising in some industries. The main reasons are: one is due to the lack of input deduction in some industries and lack of equipment, materials and purchased services; Second, in the process of carrying out the new tax policy in our country, the core business of the labor-intensive service industries are less affected. The reform was carried out mainly in the fixed assets purchase of deduction. It has more influence on the labor-intensive service industries, and it is not conducive to absorb employment.

Therefore, in the course of implementing the policy, we 
need to give consideration to the industries which have less deduction programs and labor-intensive service industries, and consider the industries' tax burden and social employment.

\subsection{Suggestions for Improving the Policy of Replacing Business Tax with VAT}

\subsubsection{Setting the Reasonable Tax Levels Makes it Simply as Much as Possible}

Views from the international situation, a country's VAT rate is generally not more than three levels. At the present, four levels' rate in our country have already been set up. Therefore, in the process of implementing the new tax policy, with the further expansion of industries, we must not increase the rate level, according to different industries, which decreases the policy effect. At the same time, it is recommended that in all industries, in which carry out the new tax policy, tax assessment need to be implemented, relevant equilibrium need to be found to combine the tax rates between the similar industries as far as possible. For example, recording to our current tax law, those industries, like water industry, power industry, oil industry, gas industry and other related industries, which are important to people's lives, are applicable for the tax rate of $13 \%$, and transportation industry is applicable for the tax rate of $11 \%$. Therefore, in consideration of the convenience of people's life and reducing the tax burden of transportation industry, we can incorporate this two tax rates into $11 \%$, or reduce to $10 \%$. Only Setting the reasonable tax levels could ensure the elimination of double taxation and the complete chain of deduction.

\subsubsection{Take the Policy of Replacing Business Tax with VAT as an Opportunity to Accelerate the Reform of Budget Management System}

In our current tax system, VAT and business tax is the first and third largest tax respectively, among which the business tax is the first big tax of local government income. Therefore, as mentioned above, after the policy, the local governments in various regions, have less income. The local governments compete and struggle for the limited financial resources between themselves and with the central government. So, we should take the policy as an opportunity to clear and definite the responsibilities of the central government and local governments and clear the rights of property on the basis of it. Meanwhile, it is recommended that in the process of implement of the new policy, transfer payment should be taken to resolve the difficulties of the local governments' lack finance. Local governments should accelerate the construction of local tax system to get the stable tax income rather than through the transfer payment, which strengthens the reliance of the local governments to the central government.

\subsubsection{Strengthen the Administration of Tax and Improve the Level}

With the implementation of the policy, one of the major problems is the tax collection and administration. Therefore, in the process of the policy implementation, we suggest that at the beginning of the policy, close cooperation should be strengthened between national tax and land tax departments, and they should do a good job in transferring and sharing related enterprise information. Another suggestion is to strengthen the management of value-added tax invoice, especially strengthen the auditing of acting invoice action preventing the spread of falsely invoice VAT behavior. The third suggestion is to improve the tax inspection level to speed up the construction of golden tax project and timely updating related audit system because of tax evasion. At the same time, strengthen the management of tax sources; timely implement the special inspection activities on the new tax policy. The fourth suggestion is to strengthen the construction of talent team and emphasis the professional training, and improve the overall level of management of the administrative team.

\subsubsection{Perfect the Current Tax System and Strengthen the Systemic Reform of the Replacing Business Tax with VAT Policy}

As stated earlier, the implementation of the policy is the important content of tax system reform in our country. Therefore, it is suggested that in the process of the implementation of the policy we should strengthen the system of reform, catch up with other tax reform. On the one hand, our country should strengthen the construction of local governments' tax types and tax sources. On the other hand, for the obvious regressive effect of the VAT after the new tax policy was carried out, it affects income distribution. So the reform of personal income tax should be speeded up, transforming the classified collection mode to the comprehensive collection model.

\subsubsection{Supply More Preferential Tax Policy and Offer More Appropriate Care to the Developing Industries}

In the process of the new tax policy being carried in our country, the overall tax burden goes down. But in some industries, tax burden is still heavy. Therefore, this article suggests that on the one hand, preferential tax policy should be given to the industries which have the increasing tax burden, reducing the negative effect to enterprises caused by the fast growth of the tax; On the other hand, according to the characteristics of the labor-intensive industries, we may consider to reduce the labor cost and the income of the workers. Relevant preferential tax policies should be carried out according to relevant industries" situation and the need of macro economy.

Replacing business tax with VAT is the important measures of China to deepen reform, adjust industrial structure and promote the economic transformation. From it was first carried out in Shanghai in 2012 to being speeded across the country in August 2013, the reform had produced significant influence. Through the analysis to the effect of policy on the micro and macro angle of view, which had been carried out for more than one year, it provides a train of thought for the research of the policy effect. At the same time, it also put forward the reference suggestions for perfecting the Chinese new tax policy. 


\section{References}

[1] Jinghua Cui. 2007.The Tax Reform Movements of Major Developed Countries in Europe and Its Enlightenment to China. European Studies4:97-109.

[2] Mingyao Jiang.2011.The Influence of Reform in Value-Added Tax on Tax Burden of Enterprises---Based on the Analysis of Input-Output Table.Journal of Central University of Finance and Economics2:11-16.

[3] Ming Liu, Ying Cheng, Huasheng Ouyang. 2011.Political Views of Expand the Scope of Value-Added Tax Levy. Modern Finance and Economics4:15- 22.

[4] Hailing Li.2012.The Influence of VAT Expanding Circumference on Equitable Income Distribution. Research of Finance and Accounting 17:17-19.

[5] Lu Wei.2013.Analysis and Improvement of Pilot Project of 'Replacing Business Tax with VAT' in Shanghai.Taxation Research4:12-17.

[6] Zhiwei Tian, Yijian Hu.2013.The Analysis of Influence of 'Replacing Business Tax with VAT' on Tax Burden of Enterprises---Based on CGE Model Analysis. Review of Finance and Economics4:29-34.

[7] Jianyi Hu.2013.Effect Analysis of Pilot Project of 'Replacing Business Tax with VAT' in China. International Tax Law, 2:8 -11 .

[8] Shaoke Chen.2012.Effect Studies of VAT Expanding Circumference---Based on Analysis of Pilot Project of 'Replacing Business Tax with VAT'.Journal of Guizhou Institute of Finance and Economics4:46-51.

[9] Liping Deng.2013.Effect Theory of VAT and Empirical Research: Preface and Enlightenment. Taxation Research10: 3-8.

[10] Xin Zhang, Tifu An.2013.Effect Analysis of Reducing 'Replacing Business Tax with VAT'. Taxation Research

[11] 10:9-13.

[12] Zhijian Li, Yixin Gao.2013.How can 'Replacing Business Tax with VAT' Make Changes to Tax Burden of Enterprises. Management and Administration 1: 24-25.

[13] Chun Hu.2013.Studies on Influence of VAT Expanding Circumference on Tax Burden of Enterprises. Journal of Hebei University of Economics and Business 2:40- 44.

[14] Zhongyue Zhang.2014.In the Perspective of Modern Service Industry: Analysis of Existing Problems and Suggestions after Comprehensive Implementation of 'Replacing Business Tax with VAT'. Theory Circle 3:36- 41. 